\title{
Research
}

\section{Impact of Pharmacotherapy to decrease Interleukin-6 in patients with chronic rhinosinusitis without nasal polyp}

\author{
Lina Marlina*, Sinta Sari Ratunanda**, Teti Madiadipoera** \\ *Department of Otorhinolaryngology Head and Neck Surgery \\ Faculty of Medicine Universitas Kristen Indonesia, Jakarta \\ **Department of Otorhinolaryngology Head and Neck Surgery \\ Faculty of Medicine, Universitas Padjadjaran/Dr.Hasan Sadikin General Hospital, \\ Bandung
}

\begin{abstract}
Background: Chronic rhinosinusitis (CRS) is an inflammation of the nasal and paranasal sinuses mucosa, ongoing for more than 12 weeks. Even now it still creates socioeconomic problem in both developed and developing countries. Pharmacotherapy administration is essential for decreasing the severity of symptom, improving quality of life, and decreasing interleukin (IL)-6 level. Objective: To find out the effect of pharmacotherapy on severity of the symptom, quality of life, and IL-6 level. Method: Randomized clinical trial with pre and posttest design, on 20 CRS without polyp patients, divided into two groups based on skin prick test results. Both groups were equally treated with nasal irrigation, nasal corticosteroid, and antibiotic amoxicillin clavulanate for 14 days. All subjects were assessed for Visual Analog Scale (VAS) score, nasoendoscopy (NE) score, Sinonasal Outcome test (SNOT)-22, and IL-6 level. Statistical analysis was performed with Mann Whitney and Wilcoxon methods. Result: There were significant differences in total analysis results on VAS scores, NE scores, SNOT-22, and IL-6 levels in both groups, with values $p<0.05$. There was improvement in all variables after pharmacotherapy, but there was no significant difference between the case and control groups, with values $p>0.05$. Conclusion: Pharmacotherapy in both groups resulte' in reduced severity of symptoms, improved quality of lives, and decreased IL-6 levels.
\end{abstract}

Keywords: Interleukin-6, pharmacotherapy, chronic rhinosinusitis without polyp, quality of life

\section{ABSTRAK}

Latar belakang: Rinosinusitis kronik (RSK) merupakan inflamasi pada mukosa hidung dan sinus paranasal, yang berlangsung selama lebih dari 12 minggu. Hingga saat ini masih memengaruhi sosioekonomi di negara maju maupun negara berkembang. Pemberian farmakoterapi sangat penting untuk memperbaiki derajat gejala, meningkatkan kualitas hidup, dan menurunkan kadar interleukin (IL)-6. Tujuan: Mengetahui pengaruh pemberian farmakoterapi terhadap perbaikan derajat gejala, peningkatan kualitas hidup, dan penurunan kadar IL-6. Metode: Penelitian kuasi eksperimental, label terbuka pra dan pascaterapi, pada 20 penderita RSK tanpa polip, dibagi dua kelompok berdasarkan hasil uji tusuk kulit. Perlakuan pada kedua kelompok sama, diberikan irigasi hidung, kortikosteroid intranasal, dan antibiotik amoksisilin klavulanat selama 14 hari. Penelitian dilakukan dengan menilai skor Visual Analog Scale (VAS) gejala hidung, skor nasoendoskopi (NE), Sinonasal Outcome test (SNOT)-22, dan kadar IL-6. Analisis statistik menggunakan metode Mann Whitney dan Wilcoxon. Hasil: Didapati perbedaan bermakna pada hasil analisis total pada skor VAS gejala hidung, skor NE, SNOT-22, dan kadar IL-6 pada kedua kelompok dengan nilai $p<0,05$. Didapati perbaikan pada semua variabel setelah 14 hari pemberian medikamentosa maksimal, namun tidak terdapat perbedaan bermakna antara kedua kelompok dengan nilai p>0,05. Kesimpulan: Pemberian farmakoterapi pada kedua kelompok memberikan hasil berupa perbaikan derajat gejala, peningkatan kualitas hidup, dan penurunan kadar IL-6. 
Kata kunci: Interleukin-6, farmakoterapi, rinosinusitis kronik tanpa polip, kualitas hidup

Correspondence address: Lina Marlina, Department of Otorhinolaryngology Head and Neck Surgery, Faculty of Medicine Universitas Kristen Indonesia, Jakarta. E-mail: hendrika.lina@gmail.com.

\section{INTRODUCTION}

Chronic rhinosinusitis (CRS) is a global health problem affecting socioeconomic, quality of life and high morbidity rate, leading to increased health cost and decreased work efficiency. It is reported that one out of seven people may have CRS. In 2014, global prevalence of CRS reached up to $15 \%$ while in 2012 in USA, Canada, and South Korea was reported as 15\%, 9.1\%, 1.01\% respectively. The condition increases with age, peaking at 50-59 years old, and decreasing after 60 years old. ${ }^{1,2}$

CRS is an inflammation process of nasal and paranasal sinuses mucosa which has been ongoing for more than 12 weeks, characterized by two or more symptoms such as nasal blockage or nasal secretion (anterior secretion or posterior nasal drips). ${ }^{1}$

There are damage of mucosal barrier system and hemostatic disturbance leading to robust proinflammatory and inflammatory mediator reactions. Pathophysiology of CRS are affected by predisposing factors such as mucociliary clearance disturbance, persistent infection, allergy, inflammatory induced mucosal edema, anatomical abnormalities of nose and paranasal sinuses, genetics, and laryngopharyngeal reflux disease (LPR). ${ }^{1,2,3}$ Hulse et al. ${ }^{4}$ and Sharma et al. ${ }^{5}$ stated that interleukin-6 (IL-6) was a dominant proinflammatory mediator found in nasal discharge. IL-6 is produced as a response to inflammatory sensitization by IL-1, tumor necrosis factor $\alpha(\mathrm{TNF}-\alpha)$, bacterial products, and viral infections, that involves in stimulating hematopoiesis and neural differentiation, activation and proliferation of $\mathrm{T}$ and $\mathrm{B}$ lymphocyte, immunoglobulin secretion, thickening of basal membrane, subepithelial fibrosis and osteogenesis cell maturation showed on CRS mucosa. ${ }^{6}$

CRS is managed with pharmacotherapy comprises of nasal irrigation, intranasal corticosteroid, and antibiotics for two weeks up to three months to reduce severity, prevent complication, and improve quality of life..$^{1,6.7}$

Nasal irrigation uses isotonic saline solution $(\mathrm{NaCl} 0.9 \%)$. Intranasal corticosteroid prevents the production of proinflammatory mediators. ${ }^{8}$ Bachert ${ }^{9}$ found that intranasal corticosteroid usage for three to four weeks may significantly reduce CRS. In the management of CRS, selecting the correct antibiotic is very crucial, taking into consideration the ability of the antibiotic to penetrate the sinonasal mucosa and nasal discharge, so that it can eradicate the biofilm producing bacteria. First line of antibiotics is group of penicillin with amoxicillinclavulanate becomes the standard therapy for CRS to minimize resistance and maximize the capability of eradicating beta lactamase producing bacteria. ${ }^{1,3}$

The outcome of CRS therapy could be observed on improvements of the clinical signs and symptoms, quality of life assessed by sino nasal outcome test-22 (SNOT-22) questionnaire, and immunological status by measuring IL-6 concentration. SNOT-22 is a tool to subjectively measure characteristics which cannot be examined directly by attending physician like pain felt by the patients. $^{10}$

This study aimed to explore the impact of pharmacotherapy regarding the improvement of severity level, quality of life, and the decrease of IL- 6 concentration in CRS without polyp patients. 


\section{METHOD}

This is a quasi experimental open labeled observational study with pre and posttest design towards matched pair groups which were given the same therapy. The measured variables were visual analog scale (VAS) score, nasoendoscopic (NE) score, SNOT-22 score and IL-6 concentration.

There were 20 CRS patients divided into case and control groups. Case group were those with negative skin prick test result to six extracts of aeroallergen which the wheal diameter was less than $3 \mathrm{~mm}$; while those with positive result of skin prick test were designated as control group.

Both groups were given nasal irrigation with isotonic saline solution, intranasal triamcinolone acetonide (TAA), and amoxicillin-clavulanate. Observations were conducted before intervention and 14 days after intervention.

Nasal irrigation using isotonic saline solution, should be performed four to five times per day, using modified applicator in the form of $20 \mathrm{cc}$ syringe, as much as $50 \mathrm{ml} /$ nostril.

TAA, a corticosteroid with low lipophilic property and longer half-life, was intranasally sprayed to both nostrils, two sprays or $220 \mu \mathrm{g}$ each day. TAA is odorless and non irritating to nasal mucosa- ${ }^{1,11,12}$ Amoxicillin-clavulanate $625 \mathrm{mg}$ was orally given three times a day for 14 days. ${ }^{13}$

Subjects were CRS without polyp patients visiting Rhinology-Allergy Polyclinic, Department of Otorhinolaryngology Head and Neck Surgery, Hasan Sadikin General Hospital, Bandung. Inclusion criteria were CRS without polyp patients compliant with EPOS 2012 criteria, age range 18-60 years old, had not received any pharmacotherapy, and agreed to become research subjects by signing informed consent. Exclusion criteria were those who had undergone nasal and paranasal sinuses surgery, allergic to amoxicillin-clavulanate, pregnant and breastfeeding women, had received uncompleted pharmacotherapy, odontogenic derived CRS, and posterior septum deviation.

Research sample was collected from nasal secretion after twice rinsing with $\mathrm{NaCl}$ $0.9 \%$, before amoxicilin-clavulanate was given, and two weeks after the completion of maximal treatment. Sample was stored in specimen tube and examined at Clinical Pathology Department, Hasan Sadikin General Hospital for IL-6 analysis using ELISA technique (Catalog No. SEA079Hu, Cloud-Clone Corp, Texas, USA).

Independent variables in this study were severity of symptoms defined by VAS score, NE score, SNOT-22 score, and IL-6 concentration. Dependent variable was CRS without polyp. Confounding factors were age, sex, occupation with high exposure to pollutant, contactant, allergen, income, type of occupation, education level, smoking, history of atopic disease, allergic rhinitis, or any other allergic diseases. ${ }^{14-16}$

Demographic data such as age, sex, and related variables were shown in a table as frequency and percentage. IL-6 concentration was a numeric variable. All statistical tests were executed using statistical software (SPSS version 21, NY, USA). Data distribution was assessed using Shapiro Wilks test, while IL-6 analysis was performed using paired t test. The difference of VAS and SNOT-22 was analyzed using the Wilcoxon test. All results were designated as statistically significant when $p<0.05$. This study had completely fulfilled ethical consideration from the ethical committee of Faculty of Medicine, Universitas Padjadjaran (No. 495/ UN6.C1.3.2/KEPK/PN/2016) and Hasan Sadikin General Hospital (No. LB.02.01/ C02/962/I/2017). 


\section{RESULT}

In this study, female was found more than male (11:9) with most patients in the age of 21-29 years old (45\%). Based on skin prick test result, there were 13 subjects showed positive response and were assigned into control group, of which 12 subjects were sensitive to Dermatophagoides pteronyssinus (data not shown).

Table 1 showed a significant difference of VAS score between case and control groups after pharmacotherapy $(\mathrm{p}<0.005)$. Total VAS score was significantly decreased in both case and control groups. Table 2 showed total NE score in all research subjects. SNOT-22 questionnaire showed that nasal symptoms became the most relieved symptoms $(\mathrm{p}<0.05)$, except for post nasal discharge, and also thick nasal discharge (data not shown). It also occurred to ear symptoms and facial pain aspect except for dizziness and ear fullness; likewise in the sleeping pattern, energy level, and emotional aspect. A statistically significant improvement found in all aspects and overall total SNOT-22 score, before intervention and 14 days after therapy, yet failed to significantly prove the difference between both groups, especially before and after treatment. (Table 3).

Table 4 showed analysis of IL-6 level on case and control groups. There was a statistically significant decreased of IL-6 level. There was no significant difference between case and control groups on VAS, NE, SNOT-22 scores, and IL-6 level, before and after therapy.

Table 1. The difference of VAS score in case and control groups

\begin{tabular}{|c|c|c|c|c|}
\hline \multirow{3}{*}{ VAS } & \multicolumn{2}{|c|}{ Groups } & \multirow{3}{*}{ Z-Mann Whitney } & \multirow{3}{*}{ p-value } \\
\hline & Case $=7$ & Control $=13$ & & \\
\hline & $\operatorname{Mean}( \pm \mathrm{SD})$ & $\operatorname{Mean}( \pm$ SD $)$ & & \\
\hline \multicolumn{5}{|l|}{ Nasal blockage } \\
\hline Before therapy & $1.857( \pm 0.690)$ & $2.308( \pm 0.630)$ & -1.413 & 0.158 \\
\hline After therapy & $0.429( \pm 0.535)$ & $1.077( \pm 0.277)$ & -2.883 & 0.004 \\
\hline Z-Wilcoxon & -2.428 & -3.176 & & \\
\hline p-value & 0.015 & 0.001 & & \\
\hline \multicolumn{5}{|l|}{ Runny Nose } \\
\hline Before therapy & $2.714( \pm 0.756)$ & $2.538( \pm 0.519)$ & -0.447 & 0.655 \\
\hline After therapy & $1.286( \pm 0.756)$ & $1.231( \pm 0.599)$ & -0.267 & 0.789 \\
\hline Z-Wilcoxon & -2.456 & -3.153 & & \\
\hline p-value & 0.014 & 0.002 & & \\
\hline \multicolumn{5}{|l|}{ Facial Pain } \\
\hline Before therapy & $1.143( \pm 1.069)$ & $0.692( \pm 0.630)$ & -0.912 & 0.362 \\
\hline After therapy & $0.571( \pm 0.787)$ & $0.231( \pm 0.439)$ & -1.038 & 0.299 \\
\hline Z-Wilcoxon & -2.000 & -2.121 & & \\
\hline p-value & 0.046 & 0.034 & & \\
\hline \multicolumn{5}{|c|}{ Smelling disturbance } \\
\hline Before therapy & $0.429( \pm 0.535)$ & $0.385( \pm 0.506)$ & -0.187 & 0.852 \\
\hline After therapy & $0.000( \pm 0.000)$ & $0.000( \pm 0.000)$ & 0.000 & 1.000 \\
\hline Z-Wilcoxon & -1.732 & -2.236 & & \\
\hline p-value & 0.083 & 0.025 & & \\
\hline \multicolumn{5}{|l|}{ Total VAS } \\
\hline Before therapy & $6.143( \pm 1.676)$ & $5.692( \pm 1.251)$ & -0.696 & 0.486 \\
\hline $\begin{array}{l}\text { After therapy } \\
\text { Z-Wilcoxon }\end{array}$ & $\begin{array}{c}3.000( \pm 0.577) \\
-2.388\end{array}$ & $\begin{array}{c}2.538( \pm 0.519) \\
-3.213\end{array}$ & -1.655 & 0.098 \\
\hline p-value & 0.017 & 0.001 & & \\
\hline
\end{tabular}

$\overline{\mathrm{ZM}}-\mathrm{W}=$ Mann Whitney test; $\mathrm{ZW}=$ Wilcoxon test; $\mathrm{p}<0.05=$ statistically significant 
Table 2. The difference of NE score in case and control groups

\begin{tabular}{|c|c|c|c|c|}
\hline \multirow{3}{*}{ Nasoendoscopy (NE) } & \multicolumn{2}{|c|}{ Groups } & \multirow{3}{*}{ Z-Mann Whitney } & \multirow{3}{*}{ p-value } \\
\hline & Case $=7$ & Control $=13$ & & \\
\hline & $\operatorname{Mean}( \pm \mathrm{SD})$ & $\operatorname{Mean}( \pm \mathrm{SD})$ & & \\
\hline \multicolumn{5}{|l|}{ Mucosal Edema } \\
\hline Before therapy & $1.571( \pm 0.535)$ & $1.615( \pm 0.506)$ & -0.187 & 0.852 \\
\hline After therapy & $0.429( \pm 0.787)$ & $0.538( \pm 0.519)$ & -0.722 & 0.470 \\
\hline Z-Wilcoxon & -2.919 & -2.889 & & \\
\hline $\mathrm{p}$-value & 0.004 & 0.004 & & \\
\hline \multicolumn{5}{|l|}{ Nasal Secretion } \\
\hline Before therapy & $1.143( \pm 0.378)$ & $1.077( \pm 0.494)$ & -0.284 & 0.776 \\
\hline After therapy & $0.571( \pm 0.138)$ & $0.538( \pm 0.519)$ & 0.890 & 0.789 \\
\hline Z-Wilcoxon & -2.121 & -2.333 & & \\
\hline p-value & 0.034 & 0.020 & & \\
\hline \multicolumn{5}{|l|}{ Total NE Score } \\
\hline Before therapy & $2.571( \pm 0.787)$ & $2.615( \pm 0.768)$ & -0.045 & 0.964 \\
\hline After therapy & $1.000( \pm 0,212)$ & $1.000( \pm 0.408)$ & -0.574 & 0.566 \\
\hline Z-Wilcoxon & -2.913 & -3.140 & & \\
\hline p-value & 0.004 & 0.002 & & \\
\hline
\end{tabular}

$\mathrm{Z} \mathrm{M}-\mathrm{W}=$ Mann Whitney test; $\mathrm{ZW}=$ Wilcoxon test; $\mathrm{p}<0.05=$ statistically significant

Table 3. The difference of SNOT-22 score in case and control groups

\begin{tabular}{|c|c|c|c|c|}
\hline \multirow{3}{*}{ SNOT 22} & \multicolumn{2}{|c|}{ Groups } & \multirow{3}{*}{ Z-Mann Whitney } & \multirow{3}{*}{ p-value } \\
\hline & Case $=7$ & Control $=13$ & & \\
\hline & $\operatorname{Mean}( \pm \mathrm{SD})$ & Mean $( \pm$ SD $)$ & & \\
\hline \multicolumn{5}{|c|}{ Rhinological domain } \\
\hline Before therapy & $18.429( \pm 5.318)$ & $20.000( \pm 4.882)$ & -0.726 & 0.468 \\
\hline After therapy & $10.714( \pm 3.546)$ & $10.615( \pm 3.664)$ & -0.080 & 0.936 \\
\hline Z-Wilcoxon & -2.946 & -3.194 & & \\
\hline p-value & 0.003 & 0.001 & & \\
\hline \multicolumn{5}{|l|}{ Ear/facial domain } \\
\hline Before therapy & $4.714( \pm 2.984)$ & $3.769( \pm 3.219)$ & -0.610 & 0.542 \\
\hline After therapy & $2.143( \pm 1.952)$ & $1.538( \pm 1.561)$ & -0.653 & 0.514 \\
\hline Z-Wilcoxon & -2.816 & -2.949 & & \\
\hline p-value & 0.005 & 0.003 & & \\
\hline \multicolumn{5}{|l|}{ Sleep domain } \\
\hline Before therapy & $10.143( \pm 3.891)$ & $10.692( \pm 4.231)$ & -0.771 & 0.441 \\
\hline After therapy & $2.143( \pm 1.676)$ & $1.231( \pm 1.739)$ & -1.318 & 0.187 \\
\hline Z-Wilcoxon & -2.952 & -3.193 & & \\
\hline p-value & 0.003 & 0.001 & & \\
\hline \multicolumn{5}{|c|}{ Psychological domain } \\
\hline Before therapy & $3.143( \pm 1.345)$ & $2.846( \pm 0.899)$ & -0.043 & 0.966 \\
\hline After therapy & $2.286( \pm 0.756)$ & $2.077( \pm 0.641)$ & -0.343 & 0.732 \\
\hline Z-Wilcoxon & -2.264 & -3.193 & & \\
\hline $\mathrm{p}$-value & 0.024 & 0.001 & & \\
\hline \multicolumn{5}{|l|}{ Overall SNOT-22 } \\
\hline Before therapy & $36.429( \pm 8.979)$ & $37.308( \pm 10.020)$ & -0.239 & 0.811 \\
\hline After therapy & $17.286( \pm 3.904)$ & $15.462( \pm 5.317)$ & -0.795 & 0.427 \\
\hline Z-Wilcoxon & -2.955 & -3.192 & & \\
\hline $\mathrm{p}$-value & 0.003 & 0.003 & & \\
\hline
\end{tabular}


Table 4. The difference of IL-6 measurement in case and control groups

\begin{tabular}{|c|c|c|c|c|}
\hline \multirow{2}{*}{$\begin{array}{c}\text { Interleukin } 6 \\
\text { (IL-6) }\end{array}$} & \multicolumn{2}{|c|}{ Groups } & \multirow{3}{*}{ Z-Mann Whitney } & \multirow{3}{*}{ p-value } \\
\hline & Case $=7$ & Control $=13$ & & \\
\hline & Mean $( \pm \mathrm{SD})$ & Mean $( \pm$ SD $)$ & & \\
\hline Before therapy & $27098.1( \pm 19264.0)$ & $35792.3( \pm 15803.9)$ & -0.832 & 0.405 \\
\hline $\begin{array}{l}\text { Atter therapy } \\
\text { Z-Wilcoxon }\end{array}$ & $\begin{array}{c}12738.7( \pm 14077.5) \\
-3.180\end{array}$ & $\begin{array}{c}18820.8( \pm 8893.1) \\
-2.934\end{array}$ & -0.753 & 0.452 \\
\hline p-value & 0.001 & 0.003 & & \\
\hline
\end{tabular}

\section{DISCUSSION}

Chronic rhinosinusitis (CRS) is inflammation on nasal and paranasal sinuses mucosa for more than 12 weeks. CRS may be managed with nasal irrigation, intranasal corticosteroid, and antibiotics for two weeks up to three months aiming to increase quality of life. ${ }^{1,7}$ Improvement of CRS may be assessed on both subjective and objective parameters. In this study, patients' subjective aspect was analyzed using VAS score and SNOT-22 questionnaire, while objective aspect was examined by attending physicians using NE score, and laboratory measurement of IL- 6 concentration.

There were decreased score on all VAS symptoms, showing that pharmacotherapy may improve symptoms felt by the patients. Total VAS analysis showed the VAS was significantly improved after therapy. Candra ${ }^{16}$ stated that nasal blockage was the symptom with the most decreased score found in VAS and NE.

Nasoendoscopy assessed edema and nasal mucosa discharge as the determinant of therapy improvement. Total score achieved was significantly decreased in all subjects. In this study, there was significantly difference between before and after therapy conditions, however there was no significant decreased of NE score between case and control groups. The process of edema and secretion is caused by inflammatory neurogenic process which happens regularly to allergic patients as the consequence of neural reflex due to inflammation. ${ }^{17}$ Neurogenic inflammation may cause rhinorrhea, nasal blockage, and itchy nose. ${ }^{3}$ Ten percent of rhinorrhea cases might be caused by vascular process. ${ }^{5}$ Another study showed that intranasal corticosteroid TAA may be given at $220 \mu \mathrm{g} /$ day along with antibiotics with significant result after three to four weeks of treatment. ${ }^{18-20}$

TAA has low lipophilic property with longer half life. Its mucosal occlusion characteristic may cause TAA to be thickened when in contact with nasal mucosa, thereby the drug could be more efficient. TAA could be stored longer in mucosa, approximately $50 \%$ in nasal conchae compared to fluticasone propionate which is only $19 \%$ stored in the conchae..$^{1,18}$

Total SNOT-22 score in this study showed significant improvement between the condition before and 14 days of therapy. This result was in line with Nanayakkara who discovered significantly different condition between SNOT-22 score before and after 14 days therapy. ${ }^{21-23} \mathrm{CRS}$ may decrease quality of life as it causes sleep disturbance and may be resolved after medical treatment is given. ${ }^{24}$

Local inflammation in CRS may be initiated with the release of IL-6 ultimately in the daytime, therefore causing fatigue, weakness and sleeping disturbance at night. ${ }^{11}$

Another variable to be concidered was immunological variable, in this case nasal IL-6 that has successfully decreased after 
medical treatment was given. The significantly decreased IL-6 measurement after medical therapy indicates that corticosteroid holds a major role in decreasing IL- 6 concentration. ${ }^{3}$ Sabino et al. ${ }^{13}$ claimed the same result of significantly decreasing nasal IL-6 concentration.

$S$. aureus and $S$. pyogenes are the most common bacteria found in CRS. Both species have the ability to produce particles that may activate a huge group of T cell subpopulation as a response to bacterial cell wall that produces biofilm. ${ }^{1-4,25}$ Amoxicillin-clavulanic acid may work on monocyte and nasal epithelial cells, causing depressed bacterial lipopolysaccharide signals.

Medical treatment may improve CRS in terms of edema symptom and facial pain. ${ }^{26}$ Nasal irrigation may prevent and rinse dominant proinflammatory mediators in CRS. ${ }^{26}$ Medical therapy in CRS without polyp has shown improvement on quality of life. The accomplishment on medical treatment could be assessed by the level of symptoms severity, improvement on quality of life, and decreased IL- 6 concentration.

In this study, all subjects were in accord with the categorization of controlled CRS, based on decreased and significant difference of VAS score on each symptoms, LundKennedy NE score, and improvement on quality of life, ultimately on SNOT-22 sleeping disturbance and psychological domain. ${ }^{1,2,11}$

This study had shown the success on medical treatment, even though there was no significant difference between the allergic (case) and non allergic (control) groups. Limitation of the study was on the cytokine used for examination, IL-6, that was commonly increased in every inflammation process in the human body. Recently, a new family member of IL-6, namely Onconstantin M(OSM) IL-6, was found to be more sensitive on inflammatory process of the nasal mucosa. ${ }^{27}$
In conclusion, medical treatment using nasal irrigation with isotonic saline solution ( $\mathrm{NaCl} 0.9 \%)$, intranasal corticosteroid triamcinolone acetonide (TAA), and oral antibiotic amoxicillin-clavulanic acid for 14 days had been proven could reduce the severity of symptoms, improve quality of life, and decrease nasal IL-6 concentration.

\section{REFERENCE}

1. Fokkens WJ, Lund VJ, Mullol J, Bachert C, Alobid I, Baroody F, et al. EPOS 2012: European position paper on rhinosinusitis and nasal polyps 2012. A summary for otorhinolaryngologists. Rhinology. 2012; 50(1): 1-12.

2. Bachert C, Pawankar R, Zhang L, Bunnag C, Fokkens WJ, Hamilos DL, et al. ICON: chronic rhinosinusitis. World Allergy Organ J. 2014; 7(1): 1-28.

3. Lee S, Lane AP. Chronic rhinosinusitis as a multifactorial inflammatory disorder. Curr Infect Dis Rep. 2011; 13(2): 159-68.

4. Hulse KE. Immune mechanisms of chronic rhinosinusitis. Curr Allergy Asthma Resp. 2016; 16(1): 1.

5. Sharma S, Watanabe S, Sivam A, Wang J, Neuwirth SJ, Perez RI, et al. Peripheral blood and tissue T regulatory cells in chronic rhinosinusitis. Am J Rhinol Allergy. 2012; 26(5): 371-9.

6. Scheckenbach K, Wagenmann M. Cytokine patterns and endotypes in acute and chronic rhinosinusitis. Curr Allergy Asthma Rep. 2016 Jan;16(1):3

7. Russell PT, Bekeny JR. Oral antibiotics and the management of chronic sinusitis: what do we know? Curr Opin Otolaryngol Head Neck Surg. 2014; 22(1): 22-6.

8. Baguley C, Brownlow A, Yeung K, Pratt E, Sacks R, Harvey R. The fate of chronic rhinosinusitis sufferers after pharmacotherapy. Int Forum Allergy Rhinol. 2014; 4(7): 525-32.

9. Bachert C, Al Bahrani N, Al Dousary S, Crombruggen K, Krysko O, Perez-Novo C, et al. The pathogenesis of CRS: An update. Curr Otorhinolaryngol Rep. 2012; 1(1): 25-32. 
10. Schalek P. Rhinosinusitis -Its impact on quality of life. $3^{\text {rd }}$ ed. Prague, Czech Republic: Medical Faculty of Charles University, 2011. p.3-26.

11. Cain RB, Lal D. Update on the management of chronic rhinosinusitis. Infect Drug Resist. 2013; 6: 1-14.

12. Pellanda C, Ottiker E, Strub C, Figueiredo $\mathrm{V}$, Rufli $\mathrm{T}$, Imanidis $\mathrm{G}$, et al. Topical bioavailability of triamcinolone acetonide: effect of dose and application frequency. Arch Dermatol Res. 2006; 298(5): 221-30.

13. Sabino HAC, Valera FCP, Aragon DC, Fantucci MZ, Titoneli CC, Martinez R, et al. Amoxicillin-clavulanate for patients with acute exacerbation of chronic rhinosinusitis: a prospective, double-blinded, placebocontrolled trial. Int Forum Allergy Rh. 2017; 7(2): 135-42.

14. Juanda IJ, Madiadipoera T, Ratunanda SS. Adaptasi Budaya, Alih Bahasa Indonesia, dan Validasi Sino-Nasal Outcome Test (SNOT)-22. MKB. 2017; 49(4): 267-73.

15. Shi JB, Fu QL, Zhang H, Cheng L, Wang YJ, Zhu DD, et al. Epidemiology of chronic rhinosinusitis: Result from a cross-sectional survey in seven Chinese cities. Allergy. 2015; 70(5): 533-9

16. Candra E. Penurunan kadar IL-8 sekret mukosa hidung pada rinosinusitis kronik tanpa polip-nonalergi oleh antibiotik makrolid meningkatkan fungsi penghidu. Tesis. Universitas Padjadjaran, Bandung. 2013.

17. Undem BJ, Thomas TC. Mechanisms underlying the neuronal-based symptoms of allergy. J Allergy Clin Immunol. 2014 June; 133(6): 1521-34.

18. Karaulov AV, Tamara V, Andrey O, Mariia C, Nataiya N. Triamcinolone Acetonide versus Fluticasone Propionate in the Treatment of Perennial Allergic Rhinitis: A Randomized, Parallel-Group Trial. Int Arch Allergy Immunol. 2019; 179: 142-151.

19. Stokes M, Stacey LA, David T, Leon D, Jorge G, George G. Evaluation of patients' preferences for triamcinolone acetonide aqueous, fluticasone propionate, and mometasone furoate nasal sprays in patients with allergic rhinitis. Otolaryngol Head And Neck Surg. 2004; 131(3): 225-31.
20. Min YG, Lee KS. The role of cytokines in rhinosinusitis. J Korean Med Sci. 2000; 15(3): 255-9.

21. Alt JA, Smith TL. Chronic rhinosinusitis and sleep: a contemporary review. Int Forum Allergy Rhinol. 2013; 3(11): 941-9.

22. Lange B, Holst R, Thilsing T, Baelum J, Kjeldsen A. Quality of life and associated factors in persons with chronic rhinosinusitis in the general population: A prospective questionnaire and clinical cross-sectional study. Clin Otolaryngol. 2013; 38(6): 474-80.

23. Lee CH, Jang JH, Lee HJ, Kim IT, Chu MJ, $\mathrm{Kim} \mathrm{CD}$, et al. Clinical characteristics of allergic rhinitis according to allergic rhinitis and its impact on asthma guidelines. Clin Exp Otorhinolaryngol. 2008; 1(4): 196-200.

24. Oyer SL, Mulligan JK, Psaltis AJ, Henriquez OA, Schlosser RJ. Cytokine correlation between sinus tissue and nasal Secretions among chronic rhinosinusitis and controls. Laryngoscope. 2013; 123(12): E72-8.

25. Hamilos DL. Chronic rhinosinusitis: epidemiology and medical management. J Allergy Clin Immunol. 2011; 128(4): 693707.

26. Bhandarkar ND, Sautter NB, Kennedy DW, Smith TL. Osteitis in chronic rhinosinusitis: a review of the literature. Int Forum Allergy Rhinol. 2013; 3(5): 355-63.

27. Pothoven KL, James EN, Kathryn EH, Lydia AS, Roderick GC, Erin R, Kathleen EH, Stephanie SS, David BC, Rakesh KC, Mark CL, Atsushi K, Nirmala G, Leslie CG, Anju TP, Robert CK, Paul JB, Bruce KT, and Robert PS. Oncostatin M promotes mucosal epithelial barrier dysfunction and is elevated in eosinophilic mucosal disease. J Allergy Clin Immunol. 2015 Sep; 136(3): 740-4. 